\begin{tabular}{|l|l|l||}
\hline \multicolumn{2}{|c|}{ PublisherInfo } \\
\hline \hline PublisherName & $:$ & BioMed Central \\
\hline \hline PublisherLocation & $:$ & London \\
\hline \hline PublisherImprintName & $:$ & BioMed Central \\
\hline \hline
\end{tabular}

\title{
Proteome chips
}

\begin{tabular}{||l|l|l||}
\hline \multicolumn{2}{|c||}{ ArticleInfo } \\
\hline \hline ArticleID & $:$ & 4160 \\
\hline \hline ArticleDOI & $:$ & $10.1186 /$ gb-spotlight-20010727-01 \\
\hline \hline ArticleCitationID & $:$ & spotlight-20010727-01 \\
\hline \hline ArticleSequenceNumber & $:$ & 231 \\
\hline \hline ArticleCategory & $:$ & Research news \\
\hline ArticleFirstPage & $:$ & 1 \\
\hline \hline ArticleLastPage & $:$ & 2 \\
\hline \hline & & \\
\hline ArticleHistory & $:$ & RegistrationDate : 2001-07-27 \\
\hline \hline ArticleCopyright & $:$ & OnlineDate $\quad: 2001-07-27$ \\
\hline \hline ArticleGrants & $:$ & \\
\hline \hline ArticleContext & $:$ & 130592211 Central Ltd2001 \\
\hline \hline
\end{tabular}




\section{Jonathan B Weitzman}

Email: jonathanweitzman@hotmail.com

In the July 26 ScienceXpress, Heng Zhu and colleagues from Yale University describe the construction of a proteome microarray containing approximately $80 \%$ of all yeast proteins (ScienceXpress 2001, 10.1126/science.1062191). They built a high-quality collection of 5800 yeast open reading frames (ORFs), representing $93.5 \%$ of all yeast genes. Each ORF was fused to a glutathione-Stransferase (GST)-HisX6 tag and expressed in yeast under the inducible GAL1 promoter. Proteins were spotted at high spatial density onto nickel-coated slides (which binds to the HisX6 tag). The yeast proteome chip was then screened with biotinylated calmodulin, and protein-protein interactions were detected using Cy3-labelled streptavidin. Zhu et al. identified known partners and 33 new potential calmodulin-binding proteins, allowing them to define a common binding motif. They also screened the proteome for proteins that bind phosphatidylinositide (PI). PI liposomes containing phosphatidylcholine and biotinylated phospholipids identified 150 different protein targets, many of which are uncharacterized proteins. These results emphasize the power of proteome chip approaches for highthroughput screening of protein interactions.

\section{References}

1. ScienceXpress, [http://www.sciencexpress.org]

2. Yale University, [http://www.yale.edu]

3. Analysis of yeast protein kinases using protein chips

4. Global Analysis of Protein Activities Using Proteome Chips, [http://spine.mbb.yale.edu/ protein_chips/] 